\title{
Ethno-racialisation at the intersection of food and migration regimes: Reading processes of farm-labour substitution against the grain of migration policies in Italy (1980-present)
}

\author{
Irene Peano ${ }^{1 *}$ \\ ${ }^{1}$ University of Lisbon, Institute of Social Sciences, Av. Prof. Anibal Bettencourt, 9 | 1600-189, Portugal
}

KEYWORDS

Ethno-racialisation

Food regime

Italy

Migration regimes;

Farm-labour substitution

\author{
A BSTRACT
}

The paper puts the food regime model, as elaborated by scholars such as Harriet Friedmann and Philip McMichael, into articulation with the analysis of migration/border regimes, as proposed by critical migration scholars. If by now it is well established that the policies that regulate the mobility of migrant labour play a crucial role in enabling capitalist accumulation in contemporary global agriculture, few analyses have delved into the actual mechanisms which make this possible, and into their histories. The argument is developed by reference to the Italian case, showing how subsequent waves of substitution of Italian labourers with migrants, that began in the 1980s, have followed different patterns. It argues that these can be understood by reading them against the grain of the changes accruing in the transnational migration regime. Thus, precarisation and segmentation of the labour force in the farming sector are shown to have been actively fostered by policies which have made of undocumented or differentially included labour one of the pillars upon which globally integrated food production has relied for the past three decades. Whilst based on national-scale statistics and secondary literature, the analysis also builds upon a sustained presence and engaged participant research in some of the Italian agroindustrial enclaves that record the highest presence of migrant labour.

\footnotetext{
* Contact address: irene.peano@ics.ul.pt/irene.peano@gmail.com (I. Peano)
} 


\section{Ethno-racialisation at the intersection of food and migration regimes: Reading processes of farm-labour substitution against the grain of migration policies in Italy (1980-present)}

Whilst post-war Italian agricultural production has progressively lost ground - as far as the absolute number of both workers and hours worked are concerned, and in terms of its incidence upon total employment and gross domestic product -, in the last two decades statistics have shown an increase in the amount of waged labour, as well as the latter's growth relative to selfand family employment. Such shifts run parallel to a measured increase in productivity (Merlino 2002). If the diminishing ratio of self-employment to waged labour follows a longer-term pattern (Pugliese 1984), the recent, net increase of waged workers is to be attributed entirely to the influx of transnational migrant labour. ${ }^{1}$ This progressive substitution of familial (and often female, also and especially if hired) workforce by waves of waged, transnational migrant workers, which started in the 1980s, led several commentators to speak of the "Californisation" of Italian (and more generally European) agriculture (cf. Berlan 1986, 1987, 2001, 2008).

However, dynamics that were set in motion much earlier paved the way to the most recent processes of substitution and restructuring. Reliance on migrant labour, fragmented along ethno-racialised lines and structurally in excess of real (albeit always aleatory) demand, often paid by piece, recruited informally and subjected to periodic substitutions, is one of the pillars upon which export-oriented agro-industrial production has rested at least since the second half of the 19th century, when the first transnational "food regime" took root (McMichael 2013). In this period, the commodification of food and the rising demand for cheap supplies for the reproduction of the growing industrial workforce led to the emergence of a standard, global price for food staples, starting with wheat. If in California cereal, cattle and later fruit and

\footnotetext{
1 Throughout this paper, I rely on figures elaborated by the yearly statistical dossiers on migration published by Caritas (from 1991 until 2012, with Fondazione Migrantes from 2004) and later by IDOS (2013present), which include a section dedicated specifically to farm labour and in turn draw upon the databases of the National Institute for Social Welfare (Istituto Nazionale di Previdenza Sociale, INPS), as well as on other datasets (such as the National Statistics Institute's, ISTAT, and especially its census on agriculture).
} 
horticultural production have employed transnational (as well as US) migrants since the beginning (cf. McWilliams 1935), in the Italian case the onset of capitalist, industrial agriculture relied first on internal, seasonal migrants (cf., among others, Arlacchi 1980; Arrighi and Piselli 1987, both for the Calabrian context; Snowden 1986 for Apulia; Nani 2015 for an overview), and later on commuting, mostly female workers (Pugliese 1984), before the current phase.

This first global regime was founded on free-trade multilateralism, and on a specialisation of crops whereby industrialising centres' colonial tropical imports combined with basic grain and livestock purchases from settler colonies and other regions, including southern and eastern Europe. Across such areas of export production, the disciplining of a docile and cheap, precarious, mobile, segmented and fluctuating workforce relied, among other tools, on the refinement of ever more elaborate, legally and scientifically sanctioned "racial" and criminological classifications. These had profound and enduring implications in terms of access to citizenship and labour rights (for the Italian case, see e.g. Schneider 1998; Teti 2011; Conelli 2014, relating internal and external colonial and racialising dynamics). ${ }^{2}$ Hence, to speak of "Californisation" as a recent phenomenon risks implying the "backwardness" of (southern) European agriculture, which would have only recently "caught up" with its North American counterpart. In fact, not only has food production been a fully integrated, global process for about a century and a half at least, but some of the foundational characters of capitalist agriculture, labour racialisation among them, have been present all along, and much further back - if evolving through time. ${ }^{3}$

\footnotetext{
2 Patterns of racialisation and ethnicised substitution are, of course, as old as the slave-based colonial plantation itself (Fields 1990; Thompson 1975; Bastos 2020: 26-7 for a review of the literature), whose era is considered as the "pre-history" of the food-regime model (McMichael 2013: 22-24). Yet, 19th-century scientific racism developed specifically as a reaction to anti-slavery abolitionism (Drescher 1990; Montagu 1998; Seth 2018) and, in the Italian case, to Southern peasants' revolts.

${ }^{3}$ My research on these matters is inserted into the ERC-funded project 'The colour of labour: the racialized lives of migrants' (Advanced Grant No. 695573, PI Cristiana Bastos). For analyses of processes of labour racialization in relation to plantation economies old and new, cf. research by other project members (Bastos 2018a, 2018b, 2020; LePetitcorps 2020; Macedo forthcoming; Miller forthcoming).
} 
Starting from such premises, in this paper I explore the most recent effects and operations of those mechanisms for the extraction of surplus labour from a cheaply hired, highly mobile, vulnerable and temporary workforce. More specifically, I concentrate on the legalised forms of discrimination that have been elaborated in Italy (in compliance with the requirements of EC/EU treaties) through the regulation of trans-national migration since the 1980s. The notion of food regimes (Friedmann 1987; Friedmann and McMichael 1989) can indeed represent a useful starting point for this sort of endeavour, as it combines a focus on socio-economic patterns with an historically minded analysis of how institutional frameworks and power relations have aided such processes. The concept adopts the perspective of the agri-food industry upon the political history of capitalist production in general, and highlights "the ways in which forms of capital accumulation in agriculture constitute global power arrangements, as expressed through patterns of circulation of food" (McMichael 2009: 140).

According to one version of such model, the current food regime is characterised by "neoliberal" or "corporate" features, and was structured precisely in the 1980s around the transnational demand of manufacturing, processing and distribution inputs. Whilst economic policies have been increasingly premised upon international competition, by means of bilateral free-trade agreements, agricultural production has become progressively more dependent upon, on the one hand, multinational seed, fertiliser, phytosanitary and mechanical industries, and on the other on processing and large distribution (for an exploration of how such dynamics are accruing in some Italian agro-industrial enclaves, see Peano 2019, 2020a). Neoliberal restructuring and corporate enclosures have concomitantly determined the de-peasantisation of large sectors of the (especially Third-) world population, and encouraged their migration into urban contexts and wealthier countries.

As several scholars have argued (cf. Corrado, De Castro and Perrotta 2017), immigration flows have been instrumental in allowing farmers in Italy and other parts of Europe and the Mediterranean to withstand the increasing competition and lowering of profit margins that the latest phase of 
restructuring determined, by cutting labour costs. Such political-economic arrangements supplanted the mercantilist-industrial model in place since the end of WWII, founded upon the concept of national economy and on stateexport subsidies, most notably on the part of the United States and Europe (including food-aid and development programs which sought to neutralise socialist policies and influences). As mentioned, during this phase mechanisation and rural out-migration in the Italian context led to the feminisation of farm labour (Signorelli 1990).

Whilst interested in power and governance, food-regime scholars nevertheless have not accounted for the ways in which the regulation of migration has contributed to upholding specific types of food production, processing and circulation, despite calls for just such kind of analyses (Corrado 2017). ${ }^{4}$ Here, therefore, I propose to examine the intersection of food with migration regimes, where the latter are defined as "a space of negotiating practices" (Tsianos and Karakayali 2010: 375) made of multiple actors, producing a set of regulating procedures that seeks to govern autonomous movement, and which in turn engender forms of disenfranchisement and thus favour the extraction of surplus. ${ }^{5}$

In both instances, the notion of a regime points to the processual, multiscalar, open-ended and composite character of modes of governance, whose outcomes are the result of constant negotiations between several actors and often conflicting interests. Hence, whilst my focus is on the Italian national context, the dynamics I describe are the result of non-linear political and

\footnotetext{
${ }^{4}$ I am well aware that, as far as the Italian context is concerned, in recent years several studies have addressed different aspects of the organization of (portions of) the migrant farm-labour force in agriculture, in specific areas, also by reference to some of the implications of migration policies (e.g. Avallone 2017 for the Sele Plain; Azzeruoli 2017 for dairy farming in the Po Valley; Brovia 2018 for the district of Cuneo/Saluzzo; Caruso 2015 for the district of Caserta; Dines and Rigo 2015 for southern Italy in general; Garrapa 2016 for the Plain of Gioia Tauro; Peano 2017, 2019, 2020a for the districts of Foggia and the Plain of Gioia Tauro; Perrotta 2015 for the districts of Potenza and Foggia; Piro and Sanò 2016 for the district of Ragusa; Salvia 2020 for the district of Latina). Yet, what I am arguing here is that there has been no systematic, rigorous account of the ways in which migration policies have impacted upon patterns of ethno-racialised substitution at a national level (and the same, I would claim, goes for much research on the issue, worldwide).

${ }^{5}$ Other scholars, myself included, have employed the related notion of a "border regime", considering migration and borders as co-constitutive (Casas-Cortes et al. 2014: 15-6). The two concepts differ only in emphasis, for which reason here I retain that of "migration regime" since my focus here is on different categories of people moving.
} 
economic processes which are global in character, but which also unfold in specific ways according to location. In the case at hand, both EU and regional policies and dynamics can be seen to have concrete effects on processes of ethno-racialisation, for example.

Based on statistical evidence and secondary literature, but also deriving from knowledge acquired through years of engaged participant observation in Italian agro-industrial districts (especially Foggia and the Plain of Gioia Tauro) and in some of the migrant workers' countries of origin (especially Romania, but also Nigeria and Bulgaria), the aim of this paper is to show how institutional forms of ethno-racialised discrimination are embedded in the migration regime, and in turn how these favour the production of cheap food for global consumption. If in general terms ethno-racialisation can be defined as the process through which perceived (biological, somatic, linguistic, cultural, national) differences are reified and manipulated to create hierarchies and multiple forms of dispossession (cf., among others, Murj and Solomos 2005), here I am particularly interested in forms of institutional racism, whereby such processes are inscribed within the law.

\section{The composition of farm labour in Italy: Successive waves of ethno- racialised substitution and their specificities}

A progressive substitution of the farm-labour force in Italy began after WWII with the mass out-migration of male waged workers from rural (and especially Southern) regions, whose place was taken by women and by internal migrants. This process also aided flexibilization and precarisation, after harsh labour struggles had achieved significant results in terms of rights and entitlements. Indeed, contrary to a widely held assumption regarding migrants' complementarity to the national workforce, on account of their supposed willingness to fill the gaps left by Italians who no longer wish to take up certain jobs (considered degrading and unpalatable from the point of view of labour conditions), it is clear that substitution occurred hand-in-hand with a deterioration of the conditions of work. Tasks, wages and guarantees, 
work intensity and even forms of recruitment have rather dramatically changed in the last decades. As several scholars have pointed out, employers - in agriculture as in other sectors - have actively encouraged and sought out the cyclical substitution of the workforce to segment it and prevent their organisation (for an overview of sociological research on the subject in postwar Italy and up to the present, see Sacchetto 2013).

Indeed, when the substitution of the Italian workforce started, in the 1980s, the agricultural sector sported among the highest rates of unionisation of waged workers in Italy, close to $90 \%$ (Pugliese 1984), which dropped by at least half in the ensuing decades. Unions in the sector have lost their collective bargaining power and representativeness among workers (especially if migrants), with real wages having themselves dropped to about half of the minimum established by collective agreements in many regions, at least as far as the migrant workforce is concerned.

Besides determining a further compression of already scant salaries in terms of their purchasing power, the most recent patterns of substitution have also coincided with changes in the nature of labour itself, which have run parallel to the integration of agriculture into global supply chains. In particular, the intensification of production, both in open fields and in hot houses, which derived from the implanting of horticultural and of tree crops devoted to the export market and was actively fostered by the European Common Agricultural Policy (CAP), also led to the intensification and timecompression of tasks. Meanwhile, legally binding labour guarantees have also been eroded, most notably by the progressive liberalisation of hiring mechanisms, which are no longer the exclusive monopoly of public bodies.

Hence, in the current food regime agricultural work has become more labour-intensive and less guaranteed than in the past, at the same time as the composition of its workforce has dramatically changed. These two processes are clearly related, and derive, on the one hand, from the fact that newly arrived migrant workers are less knowledgeable about their rights, or at any rate less able to demand their respect. This is due not least to language barriers and to migrants' scant social capital, especially among the local population, 
who often perceives them as a threat or at any rate as an unwanted presence, also on account of their assumed role in eroding wages and taking up employment at any cost, given differential starting conditions. On the other hand, as this paper argues, the vulnerability of the transnational migrant workforce is actively incentivised by immigration policies that create patterns of differential inclusion and vulnerability.

Yet, and in no small part due to the processes mentioned above, accessing (and indeed assembling and elaborating) reliable statistics concerning the number and social composition of migrant farm labourers in contemporary Italy is a particularly arduous, not to say an impossible, task. Current estimates of the rates of irregularity in the agricultural sector, based on the Italian Labour Inspectorate's data for 2019, indicate that as many as $59.3 \%$ of the farms subjected to checks violated labour regulations, with $51 \%$ of their workers totally unregistered. Of these, $8.4 \%$ are undocumented migrants. ${ }^{6}$ However, such staggeringly high figures, whilst indicative of widespread breaches, cannot of course be taken to be representative. Not only is the number of inspections carried out, on which such data is based, exiguous compared to the total number of agricultural enterprises (from less than $0.4 \%$ to $3.1 \%$, depending on what kinds of farming enterprises are considered ${ }^{7}$ ), and constantly dropping through the years due to the lack of budget and personnel, but inspections themselves cannot be assumed to be carried out randomly. Furthermore, data on the rates of irregular labour is itself unreliable, since migrants working without a contract are systematically instructed to flee if labour inspectors show up in the fields, and indeed according to my own participant research experience they often do comply, regardless of their juridical status vis-à-vis immigration laws. Finally, undocumented, non-EU workers may either be unregistered or work in

\footnotetext{
${ }^{6}$ Cf. Ispettorato Nazionale del Lavoro, 2019. Rapporto annuale dell'attività di vigilanza in materia di lavoro e legislazione sociale. Available online at https://www.ispettorato.gov.it/it-it/inevidenza/Documents/Rapporto-annuale-2019-attivita-di-vigilanza-INL.pdf, accessed $16^{\text {th }}$ October 2020.

${ }_{7}$ The Labour Inspectorate's report (see fn. 6) does not specify the sort of farming enterprises it has targeted, or how it categorized them. Whilst for the National Welfare Institute (INPS) farms in Italy amounted to 187,629 in 2018, according to the National Statistics Bureau (ISTAT), which includes more types in the category, these would total 1.5 million in 2017.
} 
somebody else's name (usually a fellow national or at any rate someone from nearby countries, who may or may not be employed in agriculture), making attempts at calculating their incidence upon the workforce even harder to estimate.

On the other hand, fraudulent practices of worker registration are widespread, especially in the poorer regions of Italy (and therefore mostly in the south), on the part of farmers in agreement with the un- or underemployed, or of those employed informally in other sectors. The latter correspond a flat rate to a complacent farmer, who will thereby enrol them and pay social insurance on their behalf, so that they will be able to access benefits of various kinds, from maternity leave to unemployment subsidies. Thus, official figures on farm labourers are skewed both ways: on the one hand, they include "bogus farm hands" (falsi braccianti), mostly but not exclusively of Italian citizenship, whilst on the other many (both Italian and, one must assume, most especially foreign-born) are absent. The ratio of one to the other is, once again, statistically invisible.

Furthermore, the increase in the number of registered foreign workers in the last two decades could be attributed at least in part to growing rates of (partially) regular employment across this period, due both to workers' own increased awareness of their rights (as proven by the dozens of strikes and demonstrations that they staged across the country, especially in the last 10 years) and to the resulting, increasing pressure on employers, both from the legal point of view and in terms of public imagery. In sum, the number of migrant workers can be assumed to be underestimated by official statistics, but the exact (or even approximate) rate of such miscalculation cannot be established through the available datasets.

Indeed, data itself is also extremely patchy, and mostly refers to the period after 1998. This is an indication of how the shifting migration regime determined a more accurate statistical awareness of the presence of foreignborn farm labourers in Italy, since 1998 was the year when the first comprehensive immigration bill entered into force (Law $6^{\text {th }}$ March 1998, n. 
40/legal decree $25^{\text {th }}$ July 1998, n. 286), in compliance with the requirements of the Schengen and Amsterdam treaties, also determining the (partial) regularisation of a significant proportion of workers in the sector.

Yet, even in their sheer imprecision, official figures do give a sense of the epochal shift in terms of the social composition of waged farm labour in the last decades. In 1998, foreign-born, registered employees in the farming sector amounted to about 50,000 (Colucci 2018: 109), a figure which more than doubled in two years, reaching 110,000 in 2000, out of a total of about 930,000 $(11.8 \%)$, to get to the 370,000 out of roughly 1 million (37\%) of 2018 (Caritas 2001, Magrini 2019). ${ }^{8}$ Indeed, in 2000 the agricultural sector absorbed the largest share $(46.6 \%)$ of the recently introduced quotas for labour authorization (Caritas 2001), which included both seasonal and long-term permits of stay. The current pandemic and concurrent policies limiting the freedom of movement of seasonal labourers, regardless of their nationality and legal status and especially in the months between March and June 2020 (when seasonal agricultural activities resumed after the winter break), led farmers' organisations across Europe to sound alarm bells as to the dearth of workers for highly time-sensitive harvest operations. Whilst this was portrayed as an unprecedented and totally unpredictable crisis, a further look into the recent history of employment policies in the sector might lead one to think again, at least as far as the Italian case is concerned (see also Peano 2020b).

Farmers' requests for foreign workers have been a constant feature of the agricultural labour market ever since seasonal and long-term migrantlabour quotas were instituted in 1998, with the first comprehensive immigration bill (Colucci 2018). The demand was such that in subsequent years it exceeded expectations, forcing the government, in the period between

\footnotetext{
82019 registered a minor decrease in absolute numbers, but an increase in the number of days worked by migrants, that amount to $28,6 \%$ of the total, continuing an uninterrupted upward trend (Magrini 2020). It is significant, however, that the percentage of days worked by migrants out of the total is lower than the ratio of migrant to Italian workers, probably signalling the higher impact of irregular labour for the former. Regional differences are rather marked, with Southern districts registering a decrease for the last couple of years.
} 
2000 and 2006, to repeatedly increase seasonal quotas, issuing multiple decrees in the same year..$^{9}$ In 2001, only slightly less than $50 \%(22,000)$ of new transnational migrants hired in the farming sector were recruited through seasonal labour quotas (Merlino 2002). Indeed, quotas reached their peak between 2006 and 2010, when they amounted to 80,000 yearly, the majority of which were allocated for farm labour. ${ }^{10}$ The subsequent drop in numbers, with as little as 18,000 yearly quotas issued in the last few years, is attributed, at least in part, to the conversion of seasonal permits into longer-term ones, which the law allows for after three years of seasonal entry, signalling a partial stabilisation of migrant workers in the sector, at any rate in some districts and regions (Magrini 2016, 2017, 2018, 2019). Indeed, seasonal farm-labour quotas have historically been allocated mostly to Northern regions, initially to those with a geographical proximity to the countries of origin of workers (such as Trentino Alto Adige and Veneto, that recruited workers from Poland, the Czech Republic, Slovakia, Romania, Macedonia, and Croatia), to then spread to other regions, most notably Piedmont and Emilia Romagna, and shifting to other nationalities (Albanian and Indian above all).

As this first sketch already demonstrates, the progressive substitution of the agricultural workforce in the last decades has not followed a linear pattern. Indeed, it is more accurately described as a series of waves or cycles, which inserted themselves differently in the farm-labour market depending

\footnotetext{
${ }^{9}$ For an overview of the government's decrees in this time range, cf. the report issued by the Parliament's lower chamber, "Immigrazione: Le Politiche di Programmazione", http://leg15.camera.it/cartellecomuni/leg14/RapportoAttivitaCommissioni/testi/01/01_cap09_sch01.h $\underline{\mathrm{tm}}$, retrieved $27^{\text {th }}$ January 2021.

${ }^{10}$ Comprehensive data on the exact number of authorizations (and then of actual permits) granted for seasonal quotas in farm labour is scant. In the year 2008, the only one for which I was able to source all such information, out of 80,000 seasonal labour quotas, 67,050 authorisations were requested for the farming sector $(87.6 \%$ of the total, the remaining ones being for activities related to tourist reception), of which 34,444 were granted. Out of these, about 11,000 seasonal permits were issued (Magrini 2009). In 2018, out of only 18,000 seasonal quotas, more than 14,000 authorisations were granted for the farming sector, and over 4,000 permits issued (Magrini 2019), marking a slight increase for the first time since 2010, when permits issued were 11,766 (Magrini 2011). The inversion of the negative trend continued in 2019, with 4289 permits issued (Magrini 2020). In the intervening period, both quotas and issued permits decreased progressively (Magrini 2012, 2013, 2014, 2015, 2016, 2017, 2018). Such high demand, particularly until 2010, is revealing, as is the bureaucratic bottleneck whereby issued quotas do not correspond to an equal amount of authorisations, and even less to the final number of permits granted, epitomizing the policy's fostering of irregularity ad informality.
} 
on nationality and gender. Initially, flows of immigration from different countries juxtaposed to one another and migrants progressively enlarged the foreign-born contingent of farm labourers. Typically, early arrivals found employment in agriculture, where undocumented status did not preclude informal hiring, to then move to more remunerative, stable occupations in urban centres and industrial poles. Indeed, turnover rates have been consistently high, indicating that substitution also works internally to each national group. Moreover, as for Italian workers in the past, in many cases migrants employed in other sectors also took up seasonal work in the fields as a way to earn some extra cash during holidays, making of farm labour an even more temporary occupation and thus discouraging workers from seeking better terms of employment.

Historically, Tunisians were the first transnational migrants to take up agricultural work in Italy, already in the late 1970s and early 1980s, at first totally undocumented and mainly in Sicily, from where they progressively spread to other areas, most notably the Sele Plain in the district of Salerno (Pugliese 1984) and, to a lesser extent, to other districts. In 2019 they were the $6^{\text {th }}$ nationality among registered farm workers, with 12,947 recorded jobs (Magrini 2020), still mostly located in Sicily (Magrini 2019) up from about 6,400 in 2000, and stably in the same position relative to other nationalities (Magrini 2005). Indeed, among the most represented foreign nationalities employed in farming with short-term contracts, Tunisians have been consistently the most territorially concentrated and the steadiest in terms of growth and relative numbers.

In the late 1980s, Senegalese nationals followed suit, together with Moroccans. Across the first decade of the $21^{\text {st }}$ century, recorded numbers of Senegalese workers remained relatively stable, in the order of about 3,600 (Magrini 2005), and became statistically visible in significant numbers only in 2012, when they grew to 5,193 (Magrini 2013); in 2019, they amounted to about 15,700 registered workers, in constant and sustained growth for the last decade (Magrini 2020), currently representing the $5^{\text {th }}$ foreign nationality employed in agriculture. Moroccans have been more numerous in the official 
records throughout this period, with 11,600 workers in 2005 and just over 35,700 in 2018 (Ibid.). Starting from the early 1990s came Albanians, who for the last few years have been the nationality benefiting in greatest numbers from seasonal labour quotas. Their numbers have also grown steadily over this period, from just below 10,000 in 2000 (Magrini 2005) to 33,568 in 2019 (the fourth most represented foreign nationality). Albanians are also the most territorially dispersed, with presences scattered across several districts in different parts of Italy. Thus, throughout this period (1980s - 2020), and for these nationalities, a progressive substitution can be identified, whereby transnational migrants have been employed in growing numbers in the farming sector.

The 2000s marked a dramatic shift, not just in terms of numbers, but also, significantly, in terms of national and gender composition, and in the pattern of substitution. Eastern Europeans (Poles, Romanians, Slovakians, Macedonians and, to a lesser extent, Bulgarians) became the most significant presence in the migrant farm-labour market, with very high turnover rates. Romanians are the national group which experienced the most prominent growth in the period from 2000 till 2015, swelling from 3,896 to a staggering 122,541. The most significant rate of growth took place between 2006 and 2008, when from 18,970 they reached 81,617 (Magrini 2009), but the 2001-2002 transition also registered a marked increase, from 5,891 to more than double the number $(12,425$, which became 17,061 the following year). Whilst to date they are still the most numerous foreign-national group, the presence of Romanians has begun to decline progressively since 2015 (they were 98,000 in 2019), and more markedly in southern regions. The same trend can be identified for other Eastern European workers whose countries accessed the EU in the first decade of the 2000s, with Poles anticipating the more general trend: from just over 6,000 workers in 2000, they reached 25,933 in 2009, to then start decreasing (in 2019 they amounted to 11,523 people). Bulgarians and Slovakians reached their peak in 2013 with around 13,400 and 10,500 workers respectively. From 2000 until accession, visa waivers and territorial proximity made Eastern European workers somehow progressively more in 
demand, because of the ease with which they could move and thus supply a flexible, "just-in-time", seasonal workforce that was absorbed through labour quotas. With their countries' annexation into the EU, such workers progressively lost access to the seasonal quota channels and began coming informally in even greater numbers, but the trend has been reversing for some years. In this case, thus, substitution was cyclical rather than linear, as in the cases outlined above, and is currently in its declining phase. Among non-EU citizens, Macedonians followed a similar pattern, as they kept growing till 2015 (11,346), to then decrease, whilst Moldovans and Ukrainians have grown until 2013, to then more or less stabilise their number, with about 6,600 and 5,200 workers in 2019, respectively. Taken as a whole, among the EasternEuropean contingent, women represent a higher percentage of the workforce than the average for transnational migrants, where men are the vast majority. This is especially the case for seasonal labour (Merlino 2002), highlighting the articulation of gender with nationality as categories that impact upon patterns of substitution and precarisation. Territorial distribution is on average rather homogeneous.

Workers from the Indian sub-continent, and most notably Punjabi Indians (as well as Pakistanis, if with smaller numbers, about a third of those of Indians), are the other group which experienced a marked increase in the last two decades, whilst being absent in previous years. Theirs was a steady rise that continues into the present, and whose rate is second only to that of Romanians: from about 3,000 in 2000 to 35,355 in 2019 (Pakistanis were 4,400 in 2013 and 11,178 in 2019). In this case, as in that of Tunisians, territorial concentration is very marked, but unlike what takes place with Tunisians it reflects a demand for skilled labour: because of their culturally derived expertise, workers from the sub-continent are mostly employed in cattle rearing and dairy processing, activities which are concentrated in the Po Valley and in the Latium and Campanian plains. They are hired through seasonal quotas to significant proportions, and they display the highest rate of permanent contract arrangements $(14,5 \%$ in 2019), which are rare in the sector but more common for such specialised tasks. In some cases, Indian 
nationals have themselves become farm owners. Hence, this pattern of substitution differs from those of earlier periods and of current European workers' own, in that it concerns both a territorially circumscribed and highly specific production, giving workers a certain degree of higher stability. A different situation occurs with Indian and Pakistani workers employed in the hothouses of the district of Latina (Latium), where higher degrees of exploitation and precarity persist.

As the trend that saw Eastern Europeans growing massively among the migrant farm-worker population since the early 2000s began to reverse, whilst the rate of transnational migrants among farm workers in Italy continued to rise, newer waves of substitution have made their appearance and compounded with more established, longer-term flows. In particular, Nigeria, Mali, and most recently the Gambia, have made their appearance as the countries of origin of an increasing number of migrant farm workers, making their way up into the top 15 nationalities. From 1,810, 1,143, and 201 in 2013, respectively, migrants from these countries employed in agriculture became 11.631, 7,724, and 6,721 in 2019 (Magrini 2020). As I will elaborate on in the next paragraph, this latest wave, just like previous ones, is directly related to shifts in the migration regime, which has particularly dire consequences in determining conditions of work and life.

\section{Reading numbers against the grain of shifting migration regimes}

The lack of reliable data prior to 1998, and possibly also the low official count of migrants employed in the sector up to such date, reflects the relative flexibility and informality of Italian migration policies in this period. The sudden rise in the number of migrant farm workers registered in 2000 can be attributed, on the one hand, to the mass regularisation (the fourth of its kind) adopted by the Italian government in 1998. Indeed, procedures for granting applicants the right to stay were extremely lengthy and stretched into 2000; in the end, over 217,000 undocumented migrants obtained their permits (Colucci 2018). On the other, as mentioned in the previous section, in that year the 
largest number of entry authorisations for non-nationals (46.6\%), based on the yearly quotas instituted by the same bill, were issued for farm labour (Caritas 2001). Historically, such quotas were themselves largely and commonly thwarted to regularise the positions of irregular migrants already in the country, highlighting, together with repeated reliance on amnesties, the welldocumented tendency of Italian immigration policies to be predicated on emergency solutions and to foster high rates of irregularity and illicit practices, that range from false registration to the sale of official papers such as residency and rental contracts, among others.

Hence, we can hypothesise that at least some among those who appeared in the official records of farm workers for the first time in the year 2000 were in fact already employed in the sector previously, but without figuring on account of their juridical status as undocumented migrants. As mentioned, agriculture is among the economic sectors in which the highest rates of irregularity have historically been registered. Not only does undocumented immigration status foster the breach of labour regulations, but processes of regularisation are themselves the purview of illicit practices. Hence, it is likely that some among the registered contracts that accompanied regularisation (and yearly quotas) were in fact bogus ones - which does not exclude the possibility that those holding such contracts were in fact working irregularly in agriculture, for other employers. This has been the case with several undocumented migrants who applied for regularisation through the latest amnesty bill, in the summer of 2020.

The scant presence of the Senegalese among recorded nationalities of farm workers until the 2010s, despite their early migration into Italy, can be attributed to the fact that they were perhaps more likely than others to be employed irregularly. Reasons have to do, among other factors, with more severe forms of racism and discrimination, and with the temporary nature of their employment as a way to find more stable and regular work in industry or commerce. Furthermore, the 2008 global economic crisis determined their demise from stable employment in great numbers, and their return to farm labour en masse starting from 2010. Finally, the growing presence of long-term 
Senegalese migrants in the fields compounded with that of new arrivals who reached Italy through the central Mediterranean since 2011 (I will elaborate on this last point below).

At the same time, the 1998 bill also fostered the establishment of bilateral migration agreements which went hand-in-hand with the opening of nationality-based quotas of entry for work. Agreements also contemplated the establishment of bureaus for seasonal-labour recruitment in countries such as Albania and Romania. These aimed at supporting employers and migrants in the bureaucratic procedures for application, as well as providing services such as training and the selection of candidates. In Albania they are still in place, and must have played a role in facilitating recruitment, together with personal connections and migratory chains (where one does not exclude the other). As mentioned, Albanians today are indeed the first beneficiaries of seasonal labour quotas.

As far as Schengen visa policies and EU-accession processes are concerned, these can also be interpreted as having played a role in determining the increase of Eastern European workers among farm employees in the early 2000s. Whilst Polish, Slovakian, Czech and Slovenian citizens never needed visas for short-stay entries (maximum 90 days in a 6month period), such visa waivers entered into force in 2001 for Bulgarians and in 2002 for Romanians. Yet, under no circumstances did visa waivers allow non-nationals to engage in paid activity. Thus, these policies can be seen to have facilitated the entry of migrants who must at first have worked irregularly, to only later find a way to gain their own right to work. Furthermore, besides being a secondary effect of the visa waiver, the rise of Romanian workers between 2001 and 2003 can also be attributed to the mass regularisation that was enforced in 2002 by government decree (law 30th July 2002, n. 189). Poland's earlier accession into the EU (2004) explains the anticipation by its citizens employed as farm workers in Italy of the trend which later invested Bulgarian and Romanian workers, whose countries gained EU membership in 2007. In both cases, temporary restrictions were placed on the right to work, but only for the first (which was part of a large 
group of countries obtaining membership) were these applicable in farming work. From 2004 till 2006, for citizens of Poland, the Czech Republic, Estonia, Hungary, Latvia, Lithuania, Slovakia, and Slovenia, whose countries all gained membership in 2004, right to work was subjected to approval by the Ministry of Internal Affairs, and subordinated to the issue of dedicated yearly quotas, amounting to $20,000,79,500$ and 170,000 respectively.

The lifting of such moratorium was hailed with great favour by farmers' organisations, who had pressured the government towards this end for years, given the need for a flexible supply of labour in seasonal harvests. ${ }^{11}$ Similarly, Romanian and Bulgarian citizens were also subjected to a transitory regime after their countries' accession, which lasted until 2012, such that for some sectors approval by the Ministry of Internal affairs was still required before workers could be regularly employed. This, however, was not the case for agricultural and seasonal labour, among others, explaining the sudden rise and the later decline, once liberalization in other sectors was reached. The fact that farm labour was excluded from the transitory regime is also, once again, a telling indicator of the high demand for foreign workers in this sector. The decrease of seasonal labour quotas, which started in 2011, can also be seen to have been influenced by the liberalization of the circulation and right to work of EU citizens of newly admitted Eastern European countries.

Indeed, 2011 represented a watershed for the Italian (and more generally European) migration regime in a number of ways. In that year, the attack on and then the demise of the Ghaddafi regime in Libya led to the (partial) opening up of the central Mediterranean route, which had previously been kept in check through bilateral agreements. This determined a rise in the number of West-African migrants crossing into Italy, whose rates, most markedly in the period between 2014 and 2017, more or less replaced those of non-seasonal labour quotas, which the Italian government stopped issuing in 2011 itself. This re-arrangement of the migration regime had repercussions on farm-labour employment. Those who reached Italian shores by sea have been

11 See "Neocomunitari, la fine dei Decreti flussi" La Repubblica, July 2006 - available online, http://temi.repubblica.it/metropoli-online/neocomunitari-la-fine-dei-decreti-flussi/, retrieved $11^{\text {th }}$ January 2021. 
forced to seek asylum as their only chance to hope for regularisation, given that non-seasonal labour quotas were de facto terminated.

Such "humanitarianization" of the border has also implied the expansion of the archipelago of reception facilities for asylum seekers, which in many districts have functioned as recruitment hubs for the farming sector. The near immobilisation of asylum seekers during the period when their requests are processed (which can stretch up to three years), also due to the tightening of intra-Schengen borders, and the fact that at least in their initial stages reproduction costs are covered by the reception facilities in which they are hosted, has led many to seek temporary employment in the seasonal harvests, accepting labour conditions which undercut those of longer-term migrants. Hence the growth in the numbers of Nigerian, Malian, Gambian and Pakistani workers (the latter entering the humanitarian circuit through the Balkan route).

The current tightening of Italy's Mediterranean and Eastern borders, which started in 2017, led farmers' organisations to demand, once again, an increase in seasonal quotas or other measures to make recruitment easier, due to the evident lack of labour power they experienced. Ostensibly as a response to the pandemic crisis and the ensuing lack of farm workers due to border closures, in 2020 the government announced another mass regularisation, aimed specifically at migrants employed in agriculture (as well as in domestic and care work). Yet, these measures arguably responded as much to longterm demands on the part of (mostly West-African) migrants, recently arrived in the country and employed as casual farm workers, who for years have demonstrated to obtain the right to stay (see Peano 2020b).

The planned regularisation, however, has proven a failure: out of an expected 200,000 undocumented workers in the sector (a telling number indicative of how widespread irregular employment in agriculture is, and of how this phenomenon is clearly known and understood at the institutional level), only 30,694 (15\% of the total number of requests) applied (Ministry of Internal Affairs, Emersione dei rapporti di lavoro 2020). This was mainly due to the excessively restrictive eligibility criteria and to employers' unwillingness 
to commit, both economically and in terms of the longer-term contractual obligations (including social insurance and other benefits, as well as respect of health and safety regulations, among others) they would have to sustain if their application was accepted.

Thus, the perceived lack of farm labourers refers on the one hand to certain nationalities, regions and sectors, given the high level of territorial and national segmentation of the migrant workforce. On the other hand, this "lack" signals the irregularity of a large proportion of the migrant workforce who however is already present in the country (and indeed in many ways stuck there because of undocumentedness and the restrictions that have progressively been put in place by neighbouring countries upon nonSchengen nationals' right to entry, whilst right to work has long been barred from those who have documents from other EU countries).

\section{Concluding remarks}

In this paper I have shown how Italian and more broadly EUropean migration

policies have played a role both in fostering substitution and in regulating the supply and mobility of new, potential workers in the agricultural sector, concomitantly with the latter's re-organization towards a neoliberal, corporate regime. Yet, the perceived lack of readily employable farm workers in Italy, that has represented a recurrent refrain in the public discourse of farmers' organisations, cannot be attributed entirely to tightening migration regimes and border closures, whilst these clearly affected the availability of labour. Another crucial factor must be taken into account: the constant tendency of workers to flee employment in the sector at the first occasion, given its dire conditions.

In recent years, this has been true for both Eastern European and WestAfrican workers. However, particularly the latter are kept in place by the need to periodically return to Italy from other EU countries, or to the districts where they obtained their documents, in order to renew them. This, together with the continuing (if in decreasing numbers) arrivals of new migrants through the central Mediterranean route, has provided a stable supply of seasonal 
labour power for agriculture, at least in some districts - and most notably in those where large numbers of asylum-seeker reception centres have been established in the past decade (cf. Peano forthcoming).

Whilst differences exist according to nationality, it is clear that the migration regime, and its articulation to a highly specialised and districtcentred industrial agriculture, has fostered the territorial segmentation of the workforce along ethno-racialised lines. More generally, the migration regime has actively encouraged precarity, undocumentedness and differential inclusion, pushing large numbers of migrants to seek employment in the sectors which most readily absorb those deprived of the right to work, among which agriculture features prominently. Those, such as citizens of countries that recently gained EU membership, who have mostly been enabled to seek alternatives because of their greater right to mobility, are clearly deserting farm labour in greater numbers, especially in southern regions. The shifting migration regime has thus fostered their disengagement from extremely exploitative jobs as a first step into the EU labour market.

\section{References}

Arlacchi, Pino. 1980. Mafia, Contadini e Latifondo nella Calabria Tradizionale: Le Strutture Elementari del Sottosviluppo. Bologna: Il Mulino.

Arrighi, Giovanni, and Fortunata Piselli. 1987. "Capitalist Development in Hostile Environments: Feuds, Class Struggles, and Migrations in a Peripheral Region of Southern Italy." Review (Fernand Braudel Center) 10, no. 4 (Spring): 649-751.

Avallone, Gennaro. 2017. Sfruttamento e Resistenze. Migrazioni e Agricoltura in Europa, Italia, Piana del Sele. Verona: Ombre Corte.

Azzeruoli, Vanessa. 2017. "The (Sacred) Cow Business: Narratives and Practices of the 'Ethnic Niche' of Indian Punjab Milkers in the Po Valley." In Migration and Agriculture: Mobility and Change in the Mediterranean, edited by Alessandra Corrado, Carlos de Castro, and Domenio Perrotta, 27-41. New York: Routledge. 
Bastos, Cristiana. 2018a. "Migrants Inequalities and Social Research in the 1920s: The Story of Two Portuguese Communities in New England." History and Anthropology 29, no. 2: 163-183.

Bastos, Cristiana. 2018b. "Portuguese in the Cane: The Racialization of Labour in Hawaiian Plantations." In Changing Societies: Legacies and Challenges. Vol. 1. Ambiguous Inclusions: Inside Out, Inside In, edited by Sofia Aboim, Paulo Granjo, Alice Ramos, 65-96. Lisbon: Imprensa de Ciências Sociais.

Bastos, Cristiana. 2020. "Plantation Memories, Labor Identities, and the Celebration of Heritage: The Case of Hawaii's Plantation Village". Museum Worlds: Advances in Research 8: 25-45.

Berlan, Jean Pierre. 1986. "Agriculture et Migrations." Revue européenne des migrations internationales 2, no. 3: 9-32.

Berlan, Jean Pierre. 1987. "La Agricultura y el Mercado de Trabajo ¿Una California para Europa?" Agricultura y Sociedad 42: 233-245.

Berlan, Jean Pierre. 2001. "La Longue Histoire du Modèle Californien." In Le Goût Amer de Nos Fruits et Légumes, edited by Forum Civique Européen, 15-22. Golias, Paris.

Berlan, Jean Pierre. 2008. "L'immigré Agricole Comme Modèle Sociétal?" Etudes Rurales 2, no. 182: 219-226.

Brovia, Cristina. 2018. "Migranti di Stagione. I Campi di Lavoratori Migranti Stagionali Come Problema Pubblico: Il Caso di Saluzzo." PhD diss., University of Turin.

Caritas. 2000. Dossier Statistico Immigrazione: X Rapporto. Rome: Nuova Anterem.

Caritas. 2001. Dossier Statistico Immigrazione: XI Rapporto. Rome: Nuova Anterem.

Caruso, Francesco. 2015. La Politica dei Subalterni: Organizzazione e Lotte del Bracciantato Migrante nel Sud Europa. Rome: DeriveApprodi.

Casas-Cortes, Maribel, Sebastian Cobarrubias, Nicholas De Genova, Glenda Garelli, Giorgio Grappi, Charles Heller, Sabine Hess, Bernd Kasparek, Sandro Mezzadra, Brett Neilson, Irene Peano, Lorenzo Pezzani, John Pickles, Federico Rahola, Lisa Riedner, Stephan Scheel, and Martina Tazzioli. 2015. "New Keywords: Migration and Borders." Cultural Studies 29, no.1: 55-87. 
Colucci, Michele. 2018. Storia dell'immigrazione Straniera in Italia: Dal 1945 ai Nostri Giorni. Rome: Carocci.

Conelli, Carmine. 2014. “Razza, Colonialità e Nazione: Il Progetto Coloniale Italiano tra Mezzogiorno e Africa". In Quel Che Resta Dell'impero: La Cultura Coloniale degli Italiani, edited by Valeria Deplano and Alessandro Pes, 149-167. Milan: Mimesis.

Corrado, Alessandra, Carlos de Castro, and Domenico Perrotta (eds.) 2017. Migration and Agriculture: Mobility and Change in the Mediterranean area. London: Routledge.

Corrado, Alessandra. 2017. "Agrarian Change and Migrations in The Mediterranean From a Food Regime Perspective". In Migration and Agriculture: Mobility and Change in the Mediterranean area, edited by Alesadndra Corrado, Carlos de Castro, and Domenico Perrotta, 311331. London: Routledge.

Dines, Nick, and Enrica Rigo. 2015. „Postcolonial Citizenships and The 'Refugeeization' of the Workforce: Migrant Agricultural Labor in the Italian Mezzogiorno." In Postcolonial transitions in Europe: Contexts, practices and politics, edited by Sandra Ponzanesi and Gianmaria Colpani, 151-172 . Lanham, MD: Rowman \& Littlefield.

Drescher, Seymour. 1990. "The Ending of the Slave Trade and the Evolution of European Scientific Racism." Social Science History 14, no-3: 415-450.

Fields, Barbara. 1990. "Slavery, Race, and Ideology in the United States of America." New Left Review 181 (May-June): 95-118.

Friedmann, Harriet. 1987. "International Regimes of Food and Agriculture Since 1870." In Peasants and Peasant Societies, edited by Teodor Shanin, 258-76. Oxford: Basil Blackwell.

Friedmann, Harriet, and Philip McMichael. 1989. “Agriculture and the State System: The Rise and Decline of National Agricultures, 1870 to the Present." Sociologia Ruralis 29, no. 2: 93-117.

Garrapa, Anna Mary. 2016. Braccianti Just in Time: Raccoglitori Stagionali a Rosarno e Valencia. Florence: La Casa Usher.

Le Petitcorps, Colette. 2020. “Les Sociétés de Plantation dans l'économie Globale des Services Domestiques: Le Cas de L'île Maurice." CIDADES, Comunidades e Territórios 40: 1-15. 
Macedo, Marta. Forthcoming. "Displacement, Work and Confinement: Plantation Workers in São Tomé." In Slave Subjectivities in the Iberian World, edited by Ângela Barreto Xavier, Cristina Nogueira da Silva, and Michel Cahen. London: Brill.

Magrini, Romano. 2005. "I Lavoratori Agricoli Extracomunitari". In Dossier Statistico Immigrazione: XV Rapporto, edited by Caritas and Migrantes, 298-308. Rome: Nuova Anterem.

Magrini, Romano. 2006. "I Lavoratori Immigrati in Agricoltura." In Dossier Statistico Immigrazione: XVI Rapporto, edited by Caritas and Migrantes, 284-293. Rome: Nuova Anterem.

Magrini, Romano. 2007. "I Lavoratori Stranieri nel Settore Agricolo." In Dossier Statistico Immigrazione: XVII Rapporto. Rome: Edizioni IDOS.

Magrini, Romano. 2008. "I Lavoratori Agricoli Stranieri." In Dossier Statistico Immigrazione: XVIII Rapporto. Rome: Edizioni IDOS.

Magrini, Romano. 2009. "I Lavoratori Agricoli Stranieri." In Dossier Statistico Immigrazione: XIX Rapporto. Rome: Edizioni IDOS.

Magrini, Romano. 2010. "I Lavoratori Agricoli Stranieri." In Dossier Statistico Immigrazione: XX Rapporto. Rome: Edizioni IDOS.

Magrini, Romano. 2011. "Il contributo degli Immigrati al Settore Agricolo." In Dossier Statistico Immigrazione: XXI Rapporto, 268-272. Rome: Edizioni IDOS.

Magrini, Romano. 2012. "I Lavoratori Agricoli Stranieri." In Dossier Statistico Immigrazione: XXII Rapporto. Rome: Edizioni IDOS.

Magrini, Romano. 2013. "I Lavoratori Stranieri nel Settore Agricolo." In Dossier Statistico Immigrazione 2013. Rapporto UNAR. Dalle discriminazioni ai diritti. Rome: Centro Studi e Ricerche IDOS/Immigrazione Dossier Statistico.

Magrini, Romano. 2014. "I Lavoratori Stranieri nel Settore Agricolo." In Dossier Statistico Immigrazione 2014. Rome: Centro Studi e Ricerche IDOS/Immigrazione Dossier Statistico.

Magrini, Romano. 2015. "I Lavoratori Stranieri nel Settore Agricolo." In Dossier Statistico Immigrazione 2015. Rome: Centro Studi e Ricerche IDOS/Immigrazione Dossier Statistico. 
Magrini, Romano. 2016. "I Lavoratori Stranieri nel Settore Agricolo." In Dossier Statistico Immigrazione 2016. Rome: Centro Studi e Ricerche IDOS/Immigrazione Dossier Statistico.

Magrini, Romano. 2017. "I Lavoratori Stranieri nel Settore Agricolo." In Dossier Statistico Immigrazione 2017. Rome: Centro Studi e Ricerche IDOS/Immigrazione Dossier Statistico.

Magrini, Romano. 2018. "I Lavoratori Stranieri nel Settore Agricolo." In Dossier Statistico Immigrazione 2018, 279-284. Rome: Centro Studi e Ricerche IDOS/Immigrazione Dossier Statistico.

Magrini, Romano. 2019. "I Lavoratori Stranieri nel Settore Agricolo." In Dossier Statistico Immigrazione 2019, 283-288. Rome: Centro Studi e Ricerche IDOS/Immigrazione Dossier Statistico.

Magrini, Romano. 2020. "I Lavoratori Stranieri nel Settore Agricolo." In Dossier Statistico Immigrazione 2020, 282-287. Rome: Centro Studi e Ricerche IDOS/Immigrazione Dossier Statistico.

Martin, Philip. 1985. "Migrant Labor in Agriculture: An International Comparison." International Migration Review 19, no. 1: 135-143.

McMichael, Philip. 2009. “A Food Regime Genealogy." The Journal of Peasant Studies 36, no. 1: 139-169.

McMichael, Philip. 2013. Food Regimes and Agrarian Questions. Halifax \& Winnipeg: Fernwood Publishing.

McWilliams, Carey. 1969 (1935). Factories in the Field: The Story of Migratory Farm Labor in California. Hamden: Archon Books.

Merlino, Claudia. 2002. "I Lavoratori Agricoli Extracomunitari". In Immigrazione: Dossier Statistico 2002, 12mo rapporto sull'immigrazione, edited by Caritas and Migrantes.

Rome: Nuova Anterem.

Miller, Nicholas B. Forthcoming. "Crossing Seas and Labels: British Vessels, Hawaiian Contracts and Portuguese Labour Migrants, 18781911." Portuguese Literary and Cultural Studies.

Montagu, Ashley. 1998. Man's Most Dangerous Myth: The Fallacy of Race, $6^{\text {th }}$ ed. New York: Columbia University Press.

Murji, Karim, and John Solomos (eds.) 2005. Racialization: Studies in Theory And Practice. Oxford: Oxford University Press. 
Nani, Michele. 2015. “Il Lavoro nelle Campagne." In Storia del Lavoro in Italia, Il Novecento, Vol. I. 1896-1945. Il Lavoro nell'età Industriale, edited by Stefano Musso, 58-83. Rome: Castelvecchi.

Peano, Irene. 2017. “Global Care-Commodity Chains: Labour Re/Production and Agribusiness in the District of Foggia, Southeastern Italy". Sociologia del Lavoro, 146: 24-39.

Peano, Irene. 2019. "Supply Chain Affettive tra Agro-Industria e Migrazioni, Contenimento e Rifugio." In Un Mondo Logistico: Sguardi critici su Lavoro, Migrazioni, Politica e Globalizzazione, edited by Niccolò Cuppini and Irene Peano, 63-76. Milan: Ledizioni.

Peano, Irene. 2020a. "Conflitti e Sinergie della Logistica: Enclavi AgroIndustriali, Migrazioni e ZES." Quaderni di Scienza E Politica 11: 135154.

Peano, Irene. 2020b. Missing Farm Workers in Pandemic Times: Is It Really 'the Virus's Fault'? The View from Italy. LeftEast, https://www.criticatac.ro/lefteast/.

Peano, Irene. forthcoming. "Turbulences in the Encampment Archipelago: Conflicting Mobilities between Migration, Labour and Logistics in Italian Agri-Food Enclaves." Mobilities

Perrotta, Domenico. 2015. "Agricultural Day Laborers in Southern Italy: Forms of Mobility and Resistance." South Atlantic Quarterly 114, no. 1: 195-203.

Piro, Valeria, and Giuliana Sanò. 2016. "Entering the 'Plastic Factories': Conflicts and Competition in Sicilian Greenhouses and Packinghouses. In Migration and Agriculture: Mobility and Change in the Mediterranean, edited by Alessandra Corrado, Carlos de Castro and Domenico Perrotta, 293 - 307. New York: Routledge.

Pugliese, Enrico. 1984. I Braccianti Agricoli in Italia: Tra Mercato del Lavoro e Assistenza. Milan: Franco Angeli.

Sacchetto, Devi. 2013. "Migrazioni e Lavoro nella Sociologia Italiana." In Movimenti Indisciplinati: Migrazioni, Migranti e Discipline Scientifiche, edited by Sandro Mezzadra and Maurizio Ricciardi, 50-67. Verona: Ombre Corte.

Salvia, Lucilla. 2020. “The Restructuring of Italian Agriculture and Its Impact upon Capital-Labour Relations: Labour Contracting and Exploitation 
in the Fresh Fruit and Vegetable Supply Chain of the Lazio Region, Central Italy." Journal of Agrarian Change 20, no. 1: 98-112.

Schneider, Jane (ed.) 1998. Italy's 'Southern Question': Orientalism in One Country. London: Routledge.

Seth, Suman. 2018. Difference and Disease: Medicine, Race, and the EighteenthCentury British Empire. Cambridge: Cambridge University Press.

Signorelli, Amalia. 1990. La Condizione Femminile nel Tramonto della Società Rurale Tradizionale. Annali dell'Istituto Alcide Cervi 13: 247-275. 